\title{
Globalization and GHG Emissions in the EU: Do We Need a New Development Paradigm?
}

\author{
Nela Vlahinić Lenz and Barbara Fajdetić * (D) \\ Faculty of Economics and Business, University of Rijeka, Ivana Filipovića 4, 51000 Rijeka, Croatia; \\ nela.vlahinic.lenz@efri.hr \\ * Correspondence: barbara.fajdetic@efri.hr; Tel.: +38-59-9801-0301
}

\begin{abstract}
The European Union (EU) has adopted a new development strategy based on "green" growth and announced carbon neutrality by 2050. Still, the EU's previous development path was mainly based on trade openness and globalization, with positive economic and negative climate impacts. The aim of this paper was to test the hypothesis of globalization-induced carbon emissions in order to evaluate a possible future development path. The Arellano-Bond estimator was employed for dynamic panel analysis in 26 EU countries over the period 2000-2018. A significant and positive relationship was found between economic globalization and passenger mobility and greenhouse gas (GHG) emissions, while environmental taxes can correct the negative climate effect. On the other hand, social and political dimensions of globalization reduce negative climate impacts. To achieve net zero emissions, the EU needs to continue its global climate leadership, extend the use of environmental taxes, and stimulate economic growth based on low-carbon technologies such as hydrogen, energy storage, and CCUS.
\end{abstract}

Keywords: globalization; GHG emissions; EU; green growth; development path

Citation: Vlahinić Lenz, N.; Fajdetić,

B. Globalization and GHG

Emissions in the EU: Do We

Need a New Development

Paradigm? Sustainability 2021, 13, 9936. https://doi.org/10.3390/ su13179936

Academic Editors: Marius Dan Gavriletea, Walter Leal Filho and Đula Borozan

Received: 20 July 2021

Accepted: 1 September 2021

Published: 4 September 2021

Publisher's Note: MDPI stays neutral with regard to jurisdictional claims in published maps and institutional affiliations.

\section{Introduction}

Globalization is a multidimensional process that integrates different markets and nations while trade, investment, and spill-over effects of technology and knowledge become faster and easier. The impact of globalization on the environment has often been evaluated as negative, and most empirical studies show that globalization, liberalization, and international trade cause an increase in greenhouse gas (GHG) emissions and thus environmental and climate degradation. Although climate change has been a policy focus since the adoption of the Paris Agreement in 2015, 2020 was the turning point when many countries announced their strategies to achieve climate neutrality by 2050 . This ambitious goal will only be possible through dramatic changes in the whole economy and society, while major structural changes can be expected in energy, transportation, and industry. The previous pattern of economic growth was based on the growth of world trade, investment, and mobility, so it was mainly the result of the growing globalization with an ambiguous impact on climate and environment. There are studies that have established the negative impact of globalization on GHG emissions and climate goals (e.g., Kalayci and Hayaloglu [1], Shahbaz et al. [2], Destek [3]), but on the other hand, there are papers that found positive impact on climate (e.g., Saint Akadiri et al. [4], Zafar et al. [5], Shahbaz et al. [6]). Due to the inconclusive empirical evidence thus far, the aim of this paper was to contribute to the ongoing debate on the role of globalization and economic growth on GHG emissions and climate as well as to provide policy recommendations within the new decarbonization context.

The year 2020 was not only the actual beginning of the decarbonization process, but also the year in which the global COVID-19 pandemic dramatically changed the way the economy works. Suddenly, globalization as we know it has changed, new forms have emerged, and digitization and online platforms have transformed the way we interact and 
do business. Spurred on by efforts to reduce energy consumption from fossil fuels and cut GHG emissions, the process of de-globalization and restricting mobility is beginning. The European Union has taken the fight against global warming and climate change seriously and has developed an ambitious climate policy. The package of measures to reduce GHG emissions, called the European Green Deal, includes the goal of climate neutrality in EU law with the aim of transforming its society and economy and putting them on a sustainable path. Therefore, the aim of this paper was to identify the relationship between globalization and GHG emissions in the EU and to test the hypothesis of globalizationinduced carbon emissions in order to evaluate a possible future path within the new economic and social environment. A dynamic panel data analysis was conducted for 26 EU countries (excluding Cyprus and Malta) over the period 2000-2018. The novelty of our research lies in a more complex coverage of globalization that includes different dimensions: economic, social, political, and policy orientation. Therefore, we used several independent variables: passenger transport modal split as a proxy for mobility, the KOF Globalization Index as a measure of economic, social, and political globalization, environmental taxes as a climate policy instrument, and the control variable GDP p/c as a proxy for the level of development. The obtained research results could provide some interesting policy guidelines in the new post-COVID-19 and possibly de-globalized era.

Although the paper does not refer specifically to the theory, the research is based on the Environmental Kuznets curve (EKC), which relates various indicators of environmental degradation and per capita income. The EKC was proposed by Simon Kuznets in 1955 and has been adopted in the environmental economic literature since the 1990s by many authors (Grossman and Krueger [7,8]; Lucas et al. [9]; Vincent [10]). In a wider sense, economic growth is strongly related to different aspects of globalization, so the conclusions of EKC may represent the appropriate theoretical background. According to EKC, in the early stages of economic growth, GHG emissions increase and environmental and climate quality declines, but beyond a certain level of development, the trend reverses and economic growth leads to lower GHG emissions. Environmental social scientists also support the hypothesis that interactions between society and the environment are complex (Pellow and Brehm [11]) and that most of the studies ignore holistic impacts of globalization.

The rest of this article is organized as follows. Section 2 provides a literature review on the globalization process and its impact on economic activity and environmental degradation. Section 3 explains the data and the model, while Section 4 presents the research findings. Section 5 provides the discussion and possible policy implications. Section 6 offers concluding remarks.

\section{Literature Review}

Although there is a large literature on the role of globalization, liberalization, and mobility in GHG emissions, the research findings are still inconclusive. They vary from country to country and region to region, mainly due to different levels of development, technological progress, country-specific economic structure, and environmental legislation. Therefore, this section presents research findings on several interrelated categories relevant to our research: globalization and economic growth, globalization and GHG emissions, transportation and GHG emissions, and the role of environmental taxes in achieving climate targets. In general, globalization is a long-term, multidimensional process that has become the subject of many research papers. The International Monetary Fund [12] emphasizes that globalization began in the 1980s and started with technological advances that have improved international transactions, both in trade and finance. Suci et al. [13] defined globalization as increasing integration between countries and societies in the world. Economies are interconnected around the world and more and more people consume similar goods and services and communicate in the same business language. Kacowicz [14] defined globalization as a shorthand for a series of interrelated changes: economic, ideological, technological, and cultural. Globalization includes trade liberalization, deregulation, priva- 
tization, restructuring of production, spread of financial markets, exchange of know-how and technology, and harmonization of tastes and standards. Osterhammel [15] pointed out that globalization is often identified with cheap and uniform mass production, aggressive tourism, and excessive exploitation of natural resources and environmental degradation. These practices have developed the need for and the right to identity, which has not been fostered with globalization.

Globalization affects various aspects, which is why Robertson and White [16] pointed out three main dimensions of globalization: economic, political, and cultural. Besides economic definitions, it is important to also define other dimensions. Goryakin et al. [17] stated that political globalization measures the degree of the country's international political engagement. Guzel et al. [18] argue that the role of political globalization is suppression of the inequalities created by economic globalization by forcing governments to adopt global institutions and respect human rights. Some authors have mentioned social globalization, for example, Guzel et al. [18] explained that social globalization provides cultural integration among the world's people, changes the lifestyles and consumption habits worldwide, and also allows people in remote areas of the world to communicate with each other. Gygli et al. [19] concluded that social globalization expresses the spread of ideas, information, images, and people. According to ILO [20], the social dimension of globalization is the impact of globalization on the life and work of people, their families, and whole societies. Regarding cultural globalization, Gygli et al. [19] concluded that it is related to the dispersion of Western culture via cultural goods and services such as movies, music, and other works of art. Cultural globalization is rather difficult to measure empirically, but some studies have argued that cultural globalization, which is sometimes called Americanization, brings negative consequences, especially for less developed countries [21].

Globalization is not easy to define and measure. Over time, several indicators have been developed to provide a better understanding of globalization. Although they share the same objective and cover all of the main aspects of globalization, the methodology for each index is different. The KOF Globalization Index was developed by Dreher [22] and includes 23 different variables divided into three main dimensions: economic, political, and social. In 2019, it was revised and updated by Gygli et al. [19] and expanded to 43 variables. In addition, the Maastricht Globalization Index and the New Globalization Index were developed, which include two dimensions that are subject to constant change: the cultural and the environmental dimensions. Figge and Martens [23] updated the Maastricht Globalization Index, which includes five main aspects: political, economic, socio-cultural, technological, and environmental. The New Globalization Index (NGI) was developed by Vujakovic [24] and covers the economic, social, and political spheres. The index includes 21 indicators, five of which had not been previously included in any globalization index such as the stock of portfolio investment, trademark applications by non-residents, patent applications by non-residents, student mobility abroad, and international environmental agreements.

As already mentioned, most of the studies have focused on economic globalization. Kalayci and Hayaloglu [1] stated that globalization leads to a higher volume of international trade and intensive capital movements between countries. Moreover, it contributes to more cooperation and competitiveness as well as the development of new technologies. Despite the positive effects, they highlighted the negative ones-environmental degradation, uncontrolled exploitation of natural resources and increasing poverty and inequality. Many authors have emphasized the economic aspects of globalization such as Shahbaz et al. [2], Martens and Raza [25], and Saint Akadiri et al. [26]. They all concluded that globalization integrates different markets and nations so that trade, investment, and exchange of technology and knowledge are faster and easier. Borghesi and Vercelli [27] summarized the effects of globalization into three groups. First, it increases the growth rate of income as well as per capita income; second, it spreads technological knowledge and know-how of the most developed economies; and finally, it spreads the cultural values of the most industrialized 
countries. Most of the studies have emphasized the positive effects of globalization; it allows countries to specialize in the production of certain goods and services in which they have comparative advantages or expertise, so that production requires minimal effort [13]. Kilic [28] pointed out that globalization affects economic growth through various channels, but mainly through international trade, financial integration, the labor market, and technological change. The positive changes in these channels will enhance the positive effect of globalization. Suci et al. [13], Ying et al. [29], Kilic [28], Samimi and Jenatabadi [30] studied the relationship between globalization and economic growth. Suci et al. [13] studied the impact of globalization on economic growth in ASEAN countries during 2006-2012 and found that the degree of globalization had positively influenced economic growth. Ying et al. [29] conducted a similar study on ASEAN countries during 1970-2008 and concluded that economic globalization had positive impact on economic growth while social and political globalization had a negative impact. In the case of developing countries, Kilic [28] came to similar conclusions. He also concluded that economic and political globalization increased economic growth while the social dimension of globalization had a negative impact on developing countries from 1981 to 2011. Samimi and Jenatabadi [30] empirically tested the relationship between economic globalization and economic growth in selected OIC (Organization of Islamic Cooperation countries) countries from 1980 to 2008 and found a positive and significant relationship between them. Moreover, the effect was stronger in countries with higher levels of human capital and deeper financial development.

As many studies have concluded, the process of wider globalization is complex, not restricted to the economic sphere alone, and also brings negative effects. Nistor [31] pointed out that globalization is a potential threat to developing countries as it causes the disappearance of traditional values. Moreover, liberalization and privatization lead to less government intervention in some sectors that have proven to be inefficient. Large multinational companies have entered the market of developing countries, displacing small and medium national companies to compete in the market. Dreher and Gaston [32] examined industry wage inequality, the Gini coefficient, and the measure of economic, social, and political globalization. They concluded that economic globalization increased industrial wage inequality in developed countries. Political and social globalization also had an impact on increasing inequality, but to a lesser extent. However, the impact of globalization on inequality in less developed countries was less. Khan [33] opined that despite positive effects, globalization excludes and distresses weak and disadvantaged regions. He listed some of the negative side effects as insecure livelihoods and entitlements for many people, increase in socio-economic inequalities, marginalization of certain groups such as women and their labor, environmental degradation, and emergence of conflict and violence. He pointed out that the concentration of economic activity and wealth in tripolar regions-North America, Europe, and East Asia-could lead to greater financial and economic problems in other regions such as Saharan Africa.

One of the important negative impacts of globalization is the one on climate and environment. Recently, many authors have studied the impact of globalization on environmental degradation and sustainable economic growth. One of the most prominent works in recent years [34] provides a historical perspective and concludes that the world's population, its productivity and energy consumption, and most of the changes affecting the global environment are closely linked. This extraordinary burst of consumption and productivity shows how the Earth system has deviated from its Holocene state since 1950 $\mathrm{CE}$, resulting in abrupt changes in the Earth's stratigraphic record. The new industrial age, however, brought about the greatest changes, and this research topic has been of the greatest interest in recent decades. Kasperowicz [35] investigated the relationship between $\mathrm{CO}_{2}$ emissions and economic growth in $18 \mathrm{EU}$ member states in the period 19952012. They found a negative relationship between GDP and $\mathrm{CO}_{2}$ in a long run because development of new carbon technologies allows for production at lower $\mathrm{CO}_{2}$ emissions. However, in the short run, this relationship was positive. Dinda [36] studied the impact of globalization on pollution level and pollution intensity in developed (OECD), developing 
(non-OECD) countries, and the world as a whole over the period 1965-1990. The empirical results showed that globalization helped to reduce $\mathrm{CO}_{2}$ emissions in developed countries while it increased $\mathrm{CO}_{2}$ emissions in developing countries. At the global level, the increase in globalization increased global warming. Kalayci and Hayaloglu [1] came to similar conclusions when they studied the impact of globalization and trade openness on $\mathrm{CO}_{2}$ emissions in NAFTA countries from 1990 to 2015 and their results confirmed that greater economic globalization and trade openness led to higher $\mathrm{CO}_{2}$ emissions. Another paper by Shahbaz et al. [2] examined the relationship between globalization and $\mathrm{CO}_{2}$ emissions for a much broader geographic coverage. They studied 25 developed economies in Asia, North America, Western Europe, and Oceania over the period 1970-2014 and concluded that globalization increased carbon emissions for most of the developed countries. They argued that globalization was not beneficial for the long-term health of the environment in most of the countries studied. Sabir and Gorus [37] investigated the impact of economic globalization and technological changes on environmental degradation in South Asian countries over the period 1975-2017 and their study showed that globalization measured as trade openness, FDI, and KOF index had a positive and statistically significant impact on environmental quality in terms of ecological footprint. Nevertheless, globalization may not have a negative impact on the environment if environmental laws are well implemented. Saint Akadiri et al. [4] investigated the role of globalization, energy consumption, and real income in achieving sustainable goals in Italy during the period 1970-2014. They concluded that Italy has environmental policies that are consistent with macroeconomic objectives. According to the authors, the increase in globalization and real income has reduced the impact on pollution, while environmental quality has improved, and $\mathrm{CO}_{2}$ emissions have been reduced over time. This is a positive fact that encourages the European Green Deal in reducing GHG emissions. In the battle against global warming, governments should find an effective way to reduce greenhouse gas emissions and reduce the amount of waste.

Kalayci and Hayaloglu [1] investigated the impact of globalization and trade openness on $\mathrm{CO}_{2}$ emissions in NAFTA countries. Although their results showed that greater economic globalization and trade openness led to higher $\mathrm{CO}_{2}$ emissions, they also identified a negative correlation between economic growth and $\mathrm{CO}_{2}$ emissions. This implies that countries have reached a certain level of income and that higher economic growth leads to a reduction in pollution. Dinda [36] also came to similar conclusions regarding the importance of the level of development. He investigated whether globalization causes pollution in OECD and non-OECD countries and the results showed that globalization helps to reduce pollution in developed countries (OECD members), but not in developing countries. His findings suggest that globalization helps to increase emission intensity (pollution) and relative change in emissions, and thus liberalization or openness harms the environment in developing countries and improves the environment in developed countries. This implies that developed, capital-rich countries divert some of their capital and labor to produce clean and knowledge-based technology. Opposite conclusions were argued by Zafar et al. [5] in the case of OECD countries. They examined the impact of globalization and financial development on environmental quality and confirmed the hypothesis that globalization and financial development reduce $\mathrm{CO}_{2}$ emissions. They suggested that OECD countries should improve their environmental policies through institutional development and globalization that help in $\mathrm{CO}_{2}$ reduction, especially through bilateral trade with other countries for non-polluting goods. According to them, only energy efficient products should be imported without high taxation to encourage local industries to produce and export energy efficient products to gain competitive advantage. Shahbaz et al. [6] found surprising results for China, which is often considered a country with the highest share of fossil fuels in its energy mix, the highest GHG emissions, and low environmental standards. They investigated the impact of globalization indices on carbon emissions in China. The results of econometric analysis showed that globalization increased per capita income and thus caused technological improvement that contributed to reducing the intensity of environmental degradation. At a low-income level, people 
were willing to accept increased environmental degradation in exchange for increased consumption. However, when a country achieves a higher standard of living through the globalization process, people demand better environmental quality. Typically, papers have only examined the effects of economic globalization, measured as trade openness, financial inflows, or knowledge spillover effects. As we pointed out, most of the papers have focused on economic globalization and its effects. Still, some authors have attempted to assess globalization as a much broader process with economic, social, and political dimensions. To evaluate the impact of wider globalization on the environment, Destek [3] studied the situation in 12 countries in Central and Eastern European. He found that social globalization did not affect the level of carbon emissions. Consistent with many previously mentioned studies, economic globalization increases carbon emissions while political globalization reduces pollution. This is because international environmental agreements are well implemented in these countries, and therefore, they provide proper institutional settings that help to reduce environmental degradation. Several recent research papers have found a negative relationship between the wider concept of globalization and GHG emissions, implying that higher globalization, especially in social and political terms, brings higher environmental standards and thus lower levels of greenhouse gas emissions. For example, the new published work by Destek [3] examined the various dimensions of globalization and its impact on pollution in countries of Central and Eastern European over the period 1995-2015, and the results showed that pollution increased with economic growth up to a certain level. After this level, economic growth will lead to a decrease in carbon emissions. Nevertheless, he noted that economic globalization increases carbon emissions. Increasing trade openness, inflow of foreign direct investment, and the financialization process contribute to the rising emission levels in these countries, while social globalization reduces pollution.

The role of transport in $\mathrm{CO}_{2}$ emissions has been another interesting research question and most of the studies have confirmed the increase in transport-related GHG emissions and thus the negative impact on climate. Abbes [38] investigated the factors affecting $\mathrm{CO}_{2}$ emissions from the transport sector in Eastern EU countries. The results showed that $\mathrm{CO}_{2}$ emissions from the transport sector have increased strongly in all countries and that economic activity, measured as a share of GDP, is the most important factor affecting $\mathrm{CO}_{2}$ emissions. The second most important emitter is the energy mix. Amin et al. [39] investigated whether urbanization and economic growth lead to higher emissions from the transport sector and whether renewable energy reduces them. First, they examined the relationship between renewable energy consumption, economic growth, urbanization, and $\mathrm{CO}_{2}$ emissions from the transport sector in European countries over the period 1980-2014. They found that the increase in renewable energy consumption mitigates $\mathrm{CO}_{2}$ emissions from transport, however, the urbanization increases $\mathrm{CO}_{2}$ emissions from transport. Ding et al. [40] studied the changes in transport $\mathrm{CO}_{2}$ emissions in China during the period 1991-2008 and revealed the main factors that influenced transport $\mathrm{CO}_{2}$ emissions during the observed period. They found that transport-related carbon emissions in China have been increasing more intensively since 2004, mainly due to the expansion of highways. In 2008, road freight transport revenue increased by $189 \%$ on a year-on-year basis. All the studies we found referred to the whole transport sector, and we could not find any studies using the modal split of passenger transport as a proxy for mobility, as we used in our paper.

Environmental taxes play an important role in the fight against global warming and in reducing greenhouse gas emissions, therefore, some studies have included them in their models when testing the relationship between globalization, emissions, and policy. European regulations define environmental taxes as taxes whose base has specific, negative effects on the environment [41]. Aydin and Esen [42] pointed out that the purpose of this type of tax liability is to reduce and prevent negative environmental practices and reduce waste. It should encourage the use of cleaner technologies and fuels with lower carbon footprint. Moreover, the application of environmental taxes could mitigate the negative 
effects of globalization. Aydin and Esen [42] investigated the effect of environmental taxes on $\mathrm{CO}_{2}$ emissions in the 15 EU Member States over the period 1995-2013. As expected, they found that environmental taxes had positive effects on environmental quality, but only beyond a certain threshold. On the other hand, Silajdzic and Mehic [43] studied the impact of environmental taxes on $\mathrm{CO}_{2}$ emissions in the context of emerging market economies and found different results. Their study was conducted in 10 CEE countries during the period 1995-2015. They could not confirm the effectiveness of energy taxes in reducing $\mathrm{CO}_{2}$ emissions. Transport taxes were found to be an insignificant determinant of lower $\mathrm{CO}_{2}$ emissions.

Studies on decarbonization and its impact on economic activity have become the center of research interest since the Green Deal. Still, the concept of "degrowth" is not new and can be related to the work of Georgescu-Roegen as the most prominent figure influencing the movement. Georgescu-Roegen [44] in his work argued that all natural resources are irreversibly degraded when put to use in economic activity. His work made the theoretical foundation of ecological economics. The idea of "degrowth" is a sustainable economy and society that implies the decline in economic activity based on material and energy resources. The decoupling of material consumption and economic growth is still an ongoing debate, and the central dilemma is how much material reduction is required for sustainability and whether there is an optimal scale of economy [45]. Some authors have questioned the very foundations of capitalism. For example, Euler [46] argued that capitalism is structurally unsustainable because it is based on structures of insufficiency.

The EU Green Deal triggers new research on the positive and negative economic impact of decarbonization and $\mathrm{CO}_{2}$ reduction. Recently, Pollin [47] investigated the possibility of the negative impact of decarbonization on GDP and concluded that a steady contraction of global GDP (i.e., "degrowth") did not provide a viable climate stabilization framework. His work provoked a number of reactions in the scientific public such as Schor and Jorgenson [48], who challenged Pollin's view on a growth-centric approach and argued that more socially responsible and people-centered policies could be the right answer to the climate crisis. Generally, the idea of "degrowth" focuses on the global North (i.e., developed countries) that should reduce energy and material consumption while maintaining well-being. Even a reduction in GDP is an acceptable result of degrowth scenarios that limit climate change. Martinez-Alier et al. [45] introduced the concept of sustainable degrowth. According to them, sustainable degrowth is both a concept and a popular social movement of the North that has its origins in the fields of ecological economics, social ecology, economic anthropology, and environmental and social activist groups. However, the Intergovernmental Panel for Climate Change (IPCC) and mainstream climate modeling community does not consider degrowth scenarios, but rather rely on technological progress and new technologies for $\mathrm{CO}_{2}$ removal from the atmosphere like CCS and CCUS.

\section{Data and Model}

As the aim of this study was to investigate the impact of globalization on GHG emissions in the European Union, panel data analysis was conducted for the EU-26 including the United Kingdom over the period 2000-2018. Due to a lack of data, Cyprus and Malta were excluded from the analysis. The dependent variable was GHG emissions, expressed in thousands of tons, and consists of $\mathrm{CO}_{2}, \mathrm{~N}_{2} \mathrm{O}$ in $\mathrm{CO}_{2}$ equivalent, $\mathrm{CH}_{4}$ in $\mathrm{CO}_{2}$ equivalent, $\mathrm{HFC}$ in $\mathrm{CO}_{2}$ equivalent, $\mathrm{PFC}$ in $\mathrm{CO}_{2}$ equivalent, SF6 in $\mathrm{CO}_{2}$ equivalent, and $\mathrm{NF}_{3}$ in $\mathrm{CO}_{2}$ equivalent. Table 1 provides an overview of the independent variables used in our research. 
Table 1. List of independent variables. Source: Authors.

\begin{tabular}{cccc}
\hline Symbol & Variable & Explanation & Source \\
\hline GDPPC & $\begin{array}{c}\text { Gross domestic product } \\
\text { per capita }\end{array}$ & $\begin{array}{c}\text { Measures economic activity per capita, } \\
\text { expressed in current prices, euro per capita }\end{array}$ & Eurostat \\
KOF & KOF Globalization Index * & $\begin{array}{c}\text { Measures the economic, social, and political } \\
\text { dimensions of globalization, index with a scale } \\
\text { from 1 to 100 where 100 is the maximum level }\end{array}$ & KOF Swiss Economic Institute \\
ENVI & Environmental taxes & Tax revenues in millions of Euros & Eurostat \\
PASS & $\begin{array}{c}\text { Modal split of } \\
\text { passenger transport }\end{array}$ & $\begin{array}{c}\text { Percentage of transport by passenger cars in total } \\
\text { inland passenger transport performance, } \\
\text { measured in passenger-km; passenger kilometer } \\
\text { is unit that shows one passenger travelling the } \\
\text { distance of one kilometer }\end{array}$ & Eurostat
\end{tabular}

* Note: KOF Globalization Index is based on Gygli, S, Haelg, F., Potrafke, N. and Sturm, J.E. "The KOF Globalisation Index—Revisited", Review of International Organizations, 2019, 14(3), 543-574, https:/ / doi.org/10.1007/s11558-019-09344-2.

Following this, independent variables were chosen to capture globalization: the KOF Globalization Index and Modal split of passenger transport. We also included environmental taxes as an independent variable to test the role of a specific tax policy measure in reducing pollution. Since we wanted to control our results by using income (level of development), GDP p/c was also introduced as an independent variable.

Table 2 summarizes the descriptive statistics of these seven variables for the observed countries. For each variable, we calculated the mean, standard deviation, minimum and maximum values. Our analysis included 494 observations.

Table 2. Descriptive statistics. Source: Authors.

\begin{tabular}{|c|c|c|c|c|c|c|}
\hline Variables & Units & Category & Mean & $\begin{array}{l}\text { Standard } \\
\text { Deviation }\end{array}$ & Minimum & Maximum \\
\hline \multirow{3}{*}{ GHG } & \multirow{3}{*}{$\begin{array}{l}\text { Thousand tons in } \\
\mathrm{CO}_{2} \text { equivalent }\end{array}$} & overall & 172,700 & $226,250.8$ & 632.13 & $1,031,139$ \\
\hline & & between & & $228,741.3$ & 8194.864 & $938,431.1$ \\
\hline & & within & & 27,879 & $22,660.33$ & $281,349.1$ \\
\hline \multirow{3}{*}{ GDPPC } & \multirow{3}{*}{ Euro per capita } & overall & $24,105.53$ & $16,852.61$ & 1760 & 98,640 \\
\hline & & between & & $16,416.36$ & 4660 & $76,108.42$ \\
\hline & & within & & 4934.896 & 817.1053 & $48,561.32$ \\
\hline \multirow{3}{*}{ ENVI } & \multirow{3}{*}{ Millions of euros } & overall & $11,966.07$ & $16,765.59$ & 104.39 & $63,868.08$ \\
\hline & & between & & $16,870.34$ & 393.2105 & $56,448.62$ \\
\hline & & within & & 2620.679 & 1652.497 & $28,277.78$ \\
\hline \multirow{3}{*}{ KOF } & \multirow{3}{*}{ Index } & overall & 81.72721 & 6.008871 & 60.13766 & 90.68347 \\
\hline & & between & & 5.229016 & 71.30649 & 88.6981 \\
\hline & & within & & 3.124456 & 70.26464 & 90.19242 \\
\hline \multirow{3}{*}{ PASS } & \multirow{3}{*}{$\begin{array}{l}\text { Percent of passenger cars } \\
\text { in total inland transport }\end{array}$} & overall & 80.97227 & 5.910391 & 60.8 & 92.3 \\
\hline & & between & & 5.359829 & 66.39474 & 88.88421 \\
\hline & & within & & 2.693294 & 66.13543 & 91.13543 \\
\hline
\end{tabular}

Greenhouse gas emissions in the EU Member States averaged 172,700 thousand tons of $\mathrm{CO}_{2}$ equivalent during the research period. The highest value was recorded in Germany in 2002 with 1,031,139 thousand tons, while the lowest value was recorded in Latvia in 2000 with 632 thousand tons. The average value of GDP p/c in European Union is €24,105.53 per capita. The country with the highest GDP per capita is Luxembourg- €98,640 in 2018. The highest level of environmental taxes is $€ 63,868$ million and was recorded in 2015 in the United Kingdom, while the average tax value in the European Union is $€ 11,966$ million. Regarding the KOF Globalization Index, the average value is 81.7, indicating that the EU is a highly globalized economy. The highest value was reached in the Netherlands in 2018. 
The average share of passenger cars in total domestic transport in EU Member States is $81 \%$, while the highest value was reached in Lithuania in 2009.

In order to evaluate the relationship between the selected variables and determine their influence on GHG emissions, we employed panel unit root analysis, cointegration analysis, the Granger causality test, and dynamic panel analysis.

\subsection{Panel Unit Root Test}

To analyze the stationarity of the employed variables, we conducted Im-PesaranShin [49] and Phillips-Perron unit root tests [50] Both tests allow for unbalanced panels. The following formulation is the starting point for the unit root tests.

$$
\Delta y_{i t}=\phi i y_{i, t-1}+z_{i t}^{\prime} \gamma_{i}+\epsilon_{i t}
$$

where $y_{i t}$ is variable that is being tested; $z_{i t}^{\prime} \gamma_{i}$ represents the panel-specific means; $\varphi$ is the panel-specific AR parameter. The null hypothesis for both tests is that all panels contain unit roots. The results are shown in Table 3.

Table 3. Unit root test results. Source: Authors.

\begin{tabular}{ccccc}
\hline \multirow{2}{*}{ Variables } & \multicolumn{2}{c}{ Im-Pesaran-Shin } & \multicolumn{2}{c}{$\begin{array}{c}\text { Fisher-Type Unit-Root Test } \\
\text { (Based on Phillips-Perron) }\end{array}$} \\
\cline { 2 - 5 } & \multicolumn{3}{c}{ First Differences } & First Differences \\
\cline { 2 - 5 } GHG & $1.3181(0.9063)$ & $-10.4625(0.0000)$ & $64.4039(0.1160)$ & $502.9886(0.0000)$ \\
GDPPC & $5.7441(1.0000)$ & $-7.2389(0.0000)$ & $15.4900(1.000)$ & $212.8626(0.0000)$ \\
ENVI & $5.0015(1.0000)$ & $-9.5950(0.0000)$ & $27.0624(0.9983)$ & $368.1885(0.0000)$ \\
PASS & $-0.8040(0.2107)$ & $-9.4436(0.0000)$ & $79.0671(0.0091)$ & $347.9639(0.0000)$ \\
KOF & $-0.7980(0.2124)$ & $-9.9988(0.0000)$ & $63.6817(0.1285)$ & $392.2895(0.0000)$ \\
\hline
\end{tabular}

The obtained results indicate that the variables are non-stationary. Furthermore, in the first differences, all variables have become stationary, and the null hypothesis can be rejected. We can conclude that all variables are integrated at order I.

\subsection{Panel Cointegration Analysis}

Cointegration analysis was employed in order to examine the existence of a long-run relationship among variables by using Pedroni test [51]. Cointegration test was based on the following model:

$$
y_{i t}=x_{i t}^{\prime} \beta_{i}+z_{i t}^{\prime} \gamma_{i}+e_{i t}
$$

where $y_{i t}$ is the dependent variable and $x_{i t}$ is the independent variable. $\beta_{i}$ denotes the cointegration vector that may vary across panels, $\gamma_{i}$ represents the vector of coefficients on $z_{i t}$, which is the deterministic term that controls for panel specific effects and linear time trends. $e_{i t}$ is the error term. Thus, the cointegration relationship in our research was specified as:

$$
G H G_{i t}=\gamma_{i}+\beta_{1 i} K O F_{i t}+\beta_{2 i} E N V I_{i t}+\beta_{3 i} G D P P C_{i t}+\beta_{4 i} P A S S_{i t}+e_{i t}
$$

where $\beta_{1 i}, \beta_{2 i}, \beta_{3 i}$ and $\beta_{4 i}$ represent panel specific cointegration parameters. The within dimension test allowed for panel specific cointegrating vectors and AR parameters. The in between dimension AR parameter was the same across all panels [51].

The null hypothesis indicates that there is no cointegration between variables. Rejection of the $\mathrm{H}_{0}$ implies that $e_{i t}$ is stationary and that $x_{i t}$ and $y_{i t}$ are cointegrated. The results are presented in Table 4 where it can be seen that the null hypothesis can be rejected and there was no cointegration between variables. 
Table 4. Pedroni cointegration test results. Source: Authors.

\begin{tabular}{cccccc}
\hline \multicolumn{2}{c}{ Within-Dimension } & \multicolumn{2}{c}{ Between-Dimensions } \\
\hline & Test Statistics & Prob. & & Test Statistics & Prob. \\
\hline Modified variance ratio & -2.0383 & 0.0208 & & & \\
Modified Phillips-Perron t & 1.8648 & 0.0311 & Modified Phillips-Perron t & 2.8958 & 0.0019 \\
Phillips-Perron t & -2.6133 & 0.0045 & Phillips-Perron t & -6.3825 & 0.0000 \\
Augmented Dickey-Fuller t & -2.7215 & 0.0032 & Augmented Dickey-Fuller t & -6.1343 & 0.0000 \\
\hline
\end{tabular}

Overall, we can conclude that GHG emissions, environmental taxes, GDP per capita, KOF Globalization Index, and transport are cointegrated and affect each other in the long run.

\subsection{Granger Causality Test}

To identify the direction of causal relationship, we used the Granger causality test for panel data, which implements the procedure proposed by Dumitrescu and Hurlin [52].

$$
y_{t}=\alpha+\sum_{k=1}^{K} \gamma_{i k} y_{i, t-k}+\sum_{k=1}^{K} \beta_{i k} X_{i, t-k}+\varepsilon_{i, t}
$$

where $\alpha$ is the slope of intercept; $X_{i, t}$ and $y_{i, t}$ are the observations of the two variables for individual $i$ in period $t ; k$ is the number of lag order, which is assumed to be identical for all individuals; and $\gamma_{i k}$ and $\beta_{i k}$ are the slope of coefficients. The null hypothesis is that the independent variable does not Granger-causes the dependent variable. If $\mathrm{H}_{0}$ is rejected, we can conclude that causality between $x$ and $y$ exists. The results are presented in Table 5 .

Table 5. Granger causality test results. Source: Authors.

\begin{tabular}{cccccc}
\hline & GHG & GDPPC & ENVI & KOF & PASS \\
\hline \multirow{2}{*}{ GHG } & $/$ & -0.2323 & 1.1214 & 2.1478 & 3.3127 \\
& 9.4535 & $(0.8163)$ & $(0.2621)$ & $(0.0317)$ & $(0.0009)$ \\
GDPPC & $(0.0000)$ & $/$ & -0.4461 & 2.7371 & 6.9433 \\
& 4.9532 & 4.4272 & $(0.6555)$ & $(0.0062)$ & $(0.0000)$ \\
ENVI & $(0.0000)$ & $(0.0000)$ & $/$ & 1.7132 & 6.2178 \\
& 9.8650 & 3.3576 & 0.7482 & $(0.0867)$ & $(0.0000)$ \\
KOF & $(0.0000)$ & $(0.0008)$ & $(0.4544)$ & $/$ & 6.1231 \\
& 4.8836 & 0.4214 & 0.7545 & 0.6357 & $(0.0000)$ \\
PASS & $(0.0000)$ & $(0.6734)$ & $(0.4505)$ & $(0.5250)$ & $/$ \\
& & & & & \\
\hline
\end{tabular}

The results showed that all independent variables Granger-cause greenhouse gas emissions for at least one panel unit. The bi-directional causality was detected between the KOF Globalization Index and GHG emissions, percent of passenger cars and GHG emissions, GDP per capita, and KOF Globalization Index. Table 6 shows the causality matrix indicating the relationship between variables. Arrow is indicating that there is positive causality between variables.

Table 6. Granger causality matrix. Source: Authors.

\begin{tabular}{cccccc}
\hline & GHG & GDPPC & ENVI & KOF & PASS \\
\hline GHG & $/$ & & & $\uparrow$ & $\uparrow$ \\
GDPPC & $\uparrow$ & $/$ & & $\uparrow$ & $\uparrow$ \\
ENVI & $\uparrow$ & $\uparrow$ & $/$ & $\uparrow$ & $\uparrow$ \\
KOF & $\uparrow$ & $\uparrow$ & & $/$ & $\uparrow$ \\
PASS & $\uparrow$ & & & & $/$ \\
\hline
\end{tabular}


Finally, the model is presented with the following equation:

$$
G H G_{i t}=f\left(K O F_{i t}, E N V I_{i t}, G D P P C_{i t}, P A S S_{i t}\right)
$$

Since the panel data analysis was performed, the model can be written as it follows:

$$
G H G_{i t}=\beta_{0}+\beta_{1} K O F_{i t}+\beta_{2} E N V I_{i t}+\beta_{3} G D P P C_{i t}+\beta_{4} P A S S_{i t}+\varepsilon_{i t}
$$

\section{Research Results}

For the model estimation, the dynamic panel specification was used where the lagged levels of GHG emissions were considered and the Arellano and Bond [53] estimator was applied. Our model is given as follows:

$$
G H G_{i t}=\beta_{0} G H G_{i(t-1)}+\beta_{1} K O F_{i t}+\beta_{2} E N V I_{i t}+\beta_{3} G D P P C_{i t}+\beta_{4} P A S S_{i t}+\mu_{i, t}+\varepsilon_{i, t}
$$

where $G H G_{i t}$ is the greenhouse gas emissions; $\beta_{0}, \beta_{1}, \beta_{2}, \beta_{3}, \beta_{4}$ represent the parameters to be estimated; $\mu$ is country-specific effects; and $\varepsilon$ is the error term. The Arellano and Bond estimator allowed us to eliminate unobserved panel specific heterogeneity using the first differencing transformation. The results are given in Table 7.

Table 7. Arellano and Bond dynamic panel analysis. Source: Authors.

\begin{tabular}{ccc}
\hline Dependent Variable: & Coefficients & $p$-Value \\
Greenhouse Gas Emissions (GHG) & 0.8592687 & 0.000 \\
GHG 1 -1 & -0.1772332 & 0.479 \\
GDP per capita & -0.6961468 & 0.060 \\
Environmental taxes & -1630.86 & 0.023 \\
KOF Globalization Index & 1210.295 & 0.026 \\
Passenger cars & $70,842.16$ & 0.232 \\
Constant & 0.8131 & 0.4162 \\
\hline
\end{tabular}

Note: The AR(2) test is the Arellano and Bond test for the existence of the second-order autocorrelation in first differences.

According to the results obtained, GDP per capita had a negative impact on greenhouse gas emissions. The analysis showed that an increase in GDP per capita by one euro caused a decrease in GHG emissions by $177.2 \mathrm{t}$ of $\mathrm{CO}_{2}$ equivalent. However, tests showed that the results were insignificant for the data obtained. Still, GHG emissions of the previous period have a positive and significant impact on the current level of GHG emissions. The results show that the level of GHG emissions is corrected by $859 \mathrm{t}$ of $\mathrm{CO}_{2}$ equivalent each year. Our findings regarding the KOF Globalization Index shed some new light on the impact of economic, social, and political globalization on GHG emissions in the EU. Increasing the KOF Globalization Index, which includes the economic, social, and political dimensions, reduces the negative environmental effects. More precisely, when the KOF globalization index increases by one unit, GHG emissions are reduced by 1630.86 thousand tons of $\mathrm{CO}_{2}$ equivalent. The results are significant at $5 \%$ level of significance. This is a relevant research finding for EU countries as they are all open and trade dependent. Although the EU was the first to announce a decarbonization strategy and zero-carbon target by 2050, most international partners still do not share the same ambitions. The big problem is that most of the energy produced worldwide still comes from fossil fuels. According to BP [54], oil holds the largest share of the energy mix with $33.1 \%$. The worst fossil fuel with the highest greenhouse gas emissions is coal, which still accounts for $27 \%$, natural gas has a $24.2 \%$ share, while renewable energy accounts for $11 \%$ of the total energy mix. This could pose a challenge for the European Union as most international partners have yet to announce their decarbonization strategies. This could disrupt Europe's plan to become the carbon neutral continent due to the risk of carbon leakage from the third party. To reduce this risk, the European Commission will propose a "carbon border adjustment mechanism". 
This measure will work like a carbon tax, reflecting carbon content, and raising the price of products imported from areas with looser environmental laws. This plan, along with the transportation and mobility restrictions during the pandemic and after-COVID-19, could threaten free trade and start the process of de-globalization. In addition, our model includes a new variable that has not been analyzed in the existing literature- the passenger cars ratio as a proxy for mobility. The results confirm our assumption that there is a positive and significant relationship between the passenger cars ratio and GHG emissions. The one percentage point increase in the share of passenger cars in total domestic transport leads to an increase in GHG emissions of 1210.295 thousand tons of $\mathrm{CO}_{2}$ equivalent. These results justify the new EU development strategy regarding e-mobility and a stronger introduction of electric vehicles. We also obtained interesting results regarding the relationship between environmental taxes and GHG emissions. When the level of environmental taxes increased by $€ 1$ million, the level of GHG emissions decreased by $696 \mathrm{t}$ of $\mathrm{CO}_{2}$ equivalent. This result was significant at a $10 \%$ level of significance. Finally, the AR (2) test showed no evidence of the second order autocorrelation in the first differences. A more detailed analysis is presented in Table A1 in Appendix A. Vector autoregression analysis (VAR) with exogenous variables was applied to obtain the results by each EU member country. This allowed us to observe the influence of each independent variable on the dependent one, but to also examine the influence of the lag value of the dependent variable. For this test, the model is given as follows [55].

$$
G H G_{t}=\alpha G H G_{t-1}+\beta_{0} K O F_{t}+\beta_{1} E N V I_{t}+\beta_{2} G D P P C_{t}+\beta_{3} P A S S_{t}+u_{t}
$$

According to results, the KOF Globalization Index indicated a negative and significant relationship with GHG emissions in Belgium, France, Germany, Hungary, Ireland, and Sweden. In contrast, the relationship was positive and significant in Croatia, Lithuania, and Slovakia. A positive and significant relationship between GDP per capita and GHG emissions was found in Belgium, Estonia, Greece, and Slovenia. On the other hand, a negative and significant relationship between GDP per capita and GHG emissions was found in Denmark, Luxembourg, the Netherlands, and Portugal. In other countries, this relationship was found to be insignificant. Results on environmental taxes showed a negative and significant impact on GHG emissions in only three countries: Belgium, Estonia, and Slovakia. In Hungary, Luxembourg, Poland, and Portugal, this relationship proved to be positive and significant, which implies that environmental taxes should be accompanied with other policy instruments to reach sustainable economic growth. Regarding the relationship between the share of passenger cars in total inland transportation and GHG emissions, a positive and significant relationship was found in Luxembourg, the Netherlands, and Sweden. At the same time, a negative and significant relationship was found in Croatia, Lithuania, Romania, Slovenia, and Slovakia.

\section{Discussion}

The EU Green Deal and its goal to reach a carbon-neutral economy by 2050 will require huge structural changes and a different development path that should be based on the higher intra-EU trade and less external trade, more local products, and less fossil-based mobility. Bearing in mind the fact that EU countries are mostly small or medium-sized, open, and globalized economies that are extremely dependent on trade and other flows with their economic partners, carbon neutrality will be a difficult goal to achieve. Our research results for 26 EU countries over the period 2000-2018 confirmed that there is a significant effect of globalization, economic, political, and mobility on GHG emissions. In general, our results regarding mobility and economic globalization confirm our assumption that they increase GHG emissions. We found a significant and positive relationship between economic aspects of globalization and GHG emissions and in that regard, our findings are consistent with several studies that we described in the literature review (Kalayci and Hayaloglu [1], Shahbaz et al. [2], Destek [3]). However, these studies did not examine EU countries, and because of that, we wanted to test our results by introducing the 
control variable GDP p/c as a proxy for the development level. Regardless of the fact that the development level is a multicomplex category and is not only related to the income level, it is still recognized as the most usually used development indicator. Many studies (Dinda [36], Shahbaz et al. [2], Saint Akadiri et al. [4], Kalayci and Hayaloglu [1], Destek [3]) have shown the relevance of the income level in testing the relationship between globalization and GHG emissions. Our results confirm their findings-income level is a significant variable in explaining the impact of globalization on climate. The more developed a country, the less negative impact on climate.

Considering that EU countries differ in terms of industrial, energy, and economic structure, the more developed old EU Member States have already transformed their economies toward a service-based and low energy-intensive industrial structure. Moreover, the more developed countries have been successful in using renewable energy sources and increasing energy efficiency, which is a prerequisite for reducing greenhouse gas emissions. Our results on the impact of the level of development (measured by GDP per capita) on GHG emissions are consistent with the recent empirical findings of several authors (Kalayci and Hayaloglu [1]; Zafar et al. [5]; Shahbaz et al. [6]; Destek [3]). The analysis showed that an increase in GDP per capita by one euro caused a decrease in GHG emissions by $177.2 \mathrm{t}$ of $\mathrm{CO}_{2}$ equivalent. These results again emphasize the importance of economic growth and sustainable development, which will in turn lower the GHG emissions because of the better technological solutions and developed low-carbon technologies such as renewables, battery storage, hydrogen, CCS, and CCUS. These new technologies are the result of growing investments and again, more developed countries can invest more in clean, "green", and sustainable technological solutions. Therefore, it is crucial to stimulate economic growth in the less developed new EU Member States and the spill-over effects of technology and knowledge, especially related to new low-carbon technologies. In this context, it is very important that the EU has decided to devote up to $55 \%$ of the total funds intended for the Member States in the new 2021-2027 financial period to green and smart (digital) investment projects.

Since we intend to test the role of mobility as the important aspect of economic globalization, our model includes the passenger cars ratio. The results confirm our assumption that there is a positive and significant relationship between the passenger cars ratio and GHG emissions. The one percentage point increase in the share of passenger cars in total domestic transport lead to an increase in GHG emissions of 1210.295 thousand tons of $\mathrm{CO}_{2}$ equivalent. These results are consistent with the studies mentioned in a literature review (Abbes [38]; Amin et al., [39]; Ding et al. [40]) that found strong positive relationship between transport sector activity and GHG emissions. Still, these studies did not include passenger cars, so our findings represent new empirical evidence on the role of passenger mobility. These results justify the new EU development strategy regarding e-mobility and a stronger introduction of electric vehicles.

The aim of our paper was also to examine the role of wider globalization on GHG emissions (i.e., other aspects of globalization aside from an economic one. The results were mostly consistent with the studies mentioned in the literature review. We also found that that increase in the KOF Globalization index, which includes the economic, social, and political dimensions, reduces the negative environmental effects. Our results confirm the importance of social and political globalization and the willingness to adopt environmentally and climate friendly policies and international agreements. This is a particularly important finding for the EU, which is institutionally the most complex union with 27 Member States. Even though climate change is a phenomenon that knows no geographical or national boundaries, ethnicity, or class, nationalism within economies has proven to be a substantial obstacle in multilateral climate negotiations. Conservative governments are usually against globally oriented initiatives and political agreements to reduce GHG emissions [56]. Duara [57] declared that nationalism is at the heart of all crises in the modern world and becomes entangled in its effects. When nationalism is spoken about as a political mechanism of majoritarian integration, a potential danger threatening a 
wider crisis is the incapacity of the political actors to rein in or channel popular nationalism that it has itself encouraged. He indicated that the threat to progress and security can turn protean nationalism against the state itself.

Environmental taxes represent an important policy tool that can correct the negative environmental and climate effect of mobility, trade, and economic globalization. Our results confirm the findings (Eurostat [41] and Aydin and Esen [42], but oppose the results of Silajdzic and Mehic [43]. The reason is probably in the geographical coverage because they examined 10 CEE countries during the period 1995-2015 and these new EU Member States had weak environmental legislation in that period. Therefore, they could not confirm the effectiveness of energy taxes in reducing $\mathrm{CO}_{2}$ emissions. According to our results, when the level of environmental taxes increases by $€ 1$ million in EU countries, the level of GHG emissions decreases by $696 \mathrm{t}$ of $\mathrm{CO}_{2}$ equivalent.

\section{Conclusions}

The European Union made serious policy changes to fight against global warming and implemented the first comprehensive package of measures to reduce GHG emissions. The goal of the carbon-neutral economy by 2050 will require a completely different development path compared to the present one. It would mean a higher intra-EU trade and less external trade, more local products, and less mobility. The aim of this paper was to establish the relationship between globalization and GHG emissions in the EU and to test the hypothesis of globalization-induced carbon emissions to evaluate the possible future development path in a new economic and social post-COVID-19 context. Panel data analysis was conducted for 26 EU countries over the period 2000-2018 using four independent variables covering different aspects of globalization: passenger transport modal split, KOF Globalization Index, environmental taxes, and GDP $\mathrm{p} / \mathrm{c}$ as the control variable. The dependent variable was greenhouse gas emissions. In the empirical analysis, we conducted the Im-PesaranShin and Phillips-Perron unit root test to check stationarity. Results indicate that all variables were integrated at order I. Afterward, the Pedroni test was employed and a long run relationship between GHG emissions, environmental taxes, GDP per capita, KOF Globalization Index, and transportation was found. After conducting the Granger causality test, all independent variables Granger-cause GHG emissions for at least one panel unit and a bi-directional relationship was found between the KOF Globalization Index and GHG emissions, percent of passenger cars and GHG emissions, and GDP per capita and KOF Globalization Index. After applying dynamic panel analysis, using the Arellano and Bond estimator, we found that there was a significant effect of the KOF Globalization Index, environmental taxes, and passenger transport on the level of GHG emissions. By using the dynamic panel specification, our research results revealed some interesting new insights regarding the different effects of globalization on GHG emissions in the EU. In general, all results regarding economic globalization confirm our assumption that it increases GHG emissions. We found a significant and positive relationship between mobility and economic globalization and GHG emissions. Environmental taxes represent an important policy tool that can correct this negative environmental and climate effect, though in some countries they have had the opposite effect. According to our results, GHG emissions decrease by $696 \mathrm{t}$ of $\mathrm{CO}_{2}$ equivalent when the level of environmental taxes increases by one million euros. Nevertheless, increasing the KOF Globalization Index, which includes economic, social, and political dimensions, will significantly reduce the negative environmental effects. Our results confirm the importance of social and political globalization and the willingness to adopt environmentally and climate friendly policies and international agreements. It additionally justifies the chosen EU development strategy Green Deal, which makes the EU the global leader of a climate-neutral development agenda. Another interesting result concerns the relationship between the level of development (GDP per capita) and environmental impacts. According to our model results, GDP per capita has a negative impact on GHG emissions. Therefore, it is crucial to stimulate economic growth in the less developed new EU Member States and the spill-over effects of technology and 
knowledge, especially related to new low-carbon technologies such as hydrogen, energy storage, and CCUS to transform their energy and transport sectors, which are the largest sources of GHG emissions. The relevance of the results achieved should be analyzed in the context of a dramatically changed economic and social environment and lockdown in most countries due to the COVID-19 crisis. EU countries are open, trade-dependent, and sensitive to external shocks, while most of their trading partners have not yet announced their decarbonization strategies. This could significantly complicate the fulfilment of the EU's ambitious plans for climate neutrality by 2050.

Far from being conclusive, this study allows us to open new research directions in the field of multivariate causality between globalization, renewable energy sources, economic activity, and greenhouse gas emissions, and to evaluate public policies that can contribute to carbon neutrality and green growth. There were several limitations to our research. First, data availability is a major problem, as longer time series are not available for most of the new EU Member States. For this reason, it was not possible to study structural breaks and their impact on GHG emissions. Second, the use of the KOF Globalization Index comes with some serious caveats as it is a composite index. Composite indicators, designed to simplify complex information, are widely used but can be problematic because they contain limited information on the derivation and interpretation of the individual measures. In addition, the results presented in our study refer to the European Union, and the conclusions may not be generalizable to other countries or regions due to differences in economic, political, and cultural factors. Possibilities for future research are many including testing structural breaks and their influence on the underlying. Using the new 2020 data will bring new dynamics due to the drastic changes in the economic environment caused by the COVID-19 crisis.

Author Contributions: Conceptualization: N.V.L., Methodology: B.F., Software: B.F., Validation: N.V.L., Formal Analysis: B.F., Investigation: B.F., Data Curation: B.F., Writing-Original draft; Writing-Review and Editing: N.V.L., Visualization: B.F., Supervision: N.V.L. All authors have read and agreed to the published version of the manuscript.

Funding: This work was supported by the Croatian Science Foundation under project IP-2020-021018 and the University of Rijeka under projects Uniri-drustv-18-27 and ZIP-UNIRl-130-6-20.

Institutional Review Board Statement: Not applicable.

Informed Consent Statement: Not applicable.

Data Availability Statement: Data used in research are available at the Eurostat Database and KOF Swiss Economic Institute. The links to the data are listed below: GDP per capita, available at: https://ec.europa.eu/eurostat/databrowser/view/nama_10_pc/default/table?lang=en (accessed on 30 March 2021); Environmental taxes, available at: https:/ / ec.europa.eu/eurostat/databrowser/ view/env_ac_tax/default/table?lang=en (accessed on 18 September 2020); Modal split of passenger transport, available at: https:/ / ec.europa.eu/eurostat/databrowser/view/tran_hv_psmod/default/ table?lang=en (accessed on 9 January 2021); GHG emissions, available at https://ec.europa.eu/ eurostat/databrowser/view/env_air_gge/default/table?lang=en (accessed on 9 January 2021) KOF Globalization Index, available at: https:/ / kof.ethz.ch/en/forecasts-and-indicators/indicators/kofglobalisation-index.html (accessed on 1 March 2021).

Conflicts of Interest: The authors declare no conflict of interest. 
Appendix A

Table A1. Results of VAR analysis by country. Source: Authors.

\begin{tabular}{|c|c|c|c|c|c|c|}
\hline Country & GHG t-1 & GDP pc & Environmental Taxes & KOF Globalization Index & Passenger Cars & Constant \\
\hline Austria & $0.7228016(0.000)$ & $0.2190495(0.853)$ & $1.906819(0.663)$ & $-4480.774(0.154)$ & $1578.148(0.517)$ & $268,488.5(0.380)$ \\
\hline Belgium & $0.3946987(0.033)$ & $3.138907(0.026)$ & $-6.823606(0.013)$ & $-6281.017(0.001)$ & $859.3637(0.363)$ & $524,845.4(0.009)$ \\
\hline Bulgaria & $-0.1054157(0.571)$ & $-0.7700789(0.724)$ & $8.662281(0.468)$ & $147.0242(0.831)$ & $-349.1868(0.280)$ & $66,967.28(0.107)$ \\
\hline Czech Rep. & $0.9468891(0.000)$ & $0.9958141(0.616)$ & $-7.278434(0.374)$ & $598.1968(0.707)$ & $-397.9492(0.751)$ & $-3328.587(0.979)$ \\
\hline Denmark & $0.5052018(0.020)$ & $-1.347569(0.094)$ & $2.685787(0.245)$ & $-1142.217(0.627)$ & $1632.789(0.491)$ & $32,120.24(0.907)$ \\
\hline Estonia & $-0.4996498(0.009)$ & $2.001383(0.000)$ & $-42.46801(0.000)$ & $-10.29192(0.977)$ & $266.9505(0.103)$ & $-1400.685(0.942)$ \\
\hline Finland & $0.1088209(0.652)$ & $-1.108244(0.481)$ & $-0.3060978(0.949)$ & $-192.2364(0.961)$ & $-2042.887(0.424)$ & $271,872.8(0.461)$ \\
\hline Germany & $0.4072424(0.061)$ & $-2.470997(0.594)$ & $-1.930519(0.657)$ & $-15,641.72(0.022)$ & $-11,997.8(0.583)$ & $3,122,921(0.136)$ \\
\hline Greece & $0.5234423(0.010)$ & $2.244006(0.091)$ & $-1.483054(0.673)$ & $-193.5872(0.867)$ & $-2318.804(0.195)$ & $222,390(0.140)$ \\
\hline Hungary & $0.7611109(0.000)$ & $-1.739169(0.103)$ & $9.362562(0.015)$ & $-1170.688(0.003)$ & $400.9856(0.422)$ & $77,728.23(0.000)$ \\
\hline Ireland & $0.2391991(0.278)$ & $0.0566863(0.552)$ & $0.3617103(0.853)$ & $-4058.915(0.001)$ & $95.39239(0.938)$ & $384,926.6(0.016)$ \\
\hline Italy & $0.5656705(0.023)$ & $5.637646(0.300)$ & $-2.403144(0.291)$ & $-10,062.54(0.152)$ & $1241.225(0.820)$ & $879,258(0.308)$ \\
\hline Latvia & $0.303987(0.174)$ & $-0.3834086(0.404)$ & $6.479405(0.215)$ & $391.2533(0.157)$ & $-214.5862(0.315)$ & $-5145.534(0.841)$ \\
\hline Lithuania & $0.990017(0.000)$ & $-0.6788879(0.196)$ & $-5.334695(0.499)$ & $1062.96(0.007)$ & $-923.9403(0.000)$ & $12,555.96(0.517)$ \\
\hline Luxembourg & $0.2541204(0.290)$ & $-0.0580905(0.004)$ & $10.54714(0.001)$ & $-61.32206(0.334)$ & $408.1479(0.052)$ & $-26,038.14(0.201)$ \\
\hline Netherlands & $0.0001686(0.999)$ & $-2.689056(0.081)$ & $1.63982(0.427)$ & $-1166.886(0.546)$ & 4097.953 (0.012) & $24,325.45(0.930)$ \\
\hline Portugal & $-0.1612783(0.459)$ & $-8.484335(0.031)$ & $26.97687(0.000)$ & $1285.727(0.595)$ & $217.7738(0.829)$ & $-26,272.48(0.902)$ \\
\hline Romania & $0.8035349(0.000)$ & $-0.3658909(0.861)$ & $2.582755(0.662)$ & $-250.6116(0.786)$ & $-2347.703(0.097)$ & $217,711.5(0.023)$ \\
\hline Slovakia & $0.1616561(0.389)$ & $0.563025(0.271)$ & $-8.136163(0.021)$ & $570.2826(0.005)$ & $-522.3974(0.001)$ & $31,052.72(0.021)$ \\
\hline Slovenia & $0.0874851(0.752)$ & $0.8995821(0.082)$ & $1.61092(0.608)$ & $-189.434(0.685)$ & $-1510.597(0.049)$ & $140,253.2(0.016)$ \\
\hline Spain & $1.007285(0.000)$ & $-5.68164(0.166)$ & $3.013971(0.379)$ & $165.9031(0.979)$ & $4625.001(0.181)$ & $-327,292.4(0.645)$ \\
\hline Sweden & $0.0867168(0.712)$ & $0.3205781(0.444)$ & $-1.689042(0.428)$ & $-1805.492(0.076)$ & $9098.245(0.000)$ & $-583,685.6(0.006)$ \\
\hline United Kingdom & $0.6906949(0.000)$ & $5.924057(0.224)$ & $-4.271148(0.228)$ & $-23,878.46(0.100)$ & $-10,601.81(0.460)$ & $3,214,396(0.192)$ \\
\hline
\end{tabular}




\section{References}

1. Kalayci, C.; Hayaloglu, P. The impact of economic globalization on $\mathrm{CO}_{2}$ emissions: The case of NAFTA countries. Int. J. Energy Econ. Policy 2019, 9, 356. [CrossRef]

2. Shahbaz, M.; Shahzad, S.J.H.; Mahalik, M.K.; Hammoudeh, S. Does globalisation worsen environmental quality in developed economies? Environ. Modeling Assess. 2018, 23, 141-156. [CrossRef]

3. Destek, M.A. Investigation on the role of economic, social, and political globalization on environment: Evidence from CEECs. Environ. Sci. Pollut. Res. 2020, 27, 33601-33614. [CrossRef] [PubMed]

4. Akadiri, S.S.; Alkawfi, M.M.; Uğural, S.; Akadiri, A.C. Towards achieving environmental sustainability target in Italy. The role of energy, real income and globalization. Sci. Total Environ. 2019, 671, 1293-1301. [CrossRef]

5. Zafar, M.W.; Saud, S.; Hou, F. The impact of globalization and financial development on environmental quality: Evidence from selected countries in the Organization for Economic Co-operation and Development (OECD). Environ. Sci. Pollut. Res. 2019, 26, 13246-13262. [CrossRef] [PubMed]

6. Shahbaz, M.; Khan, S.; Ali, A.; Bhattacharya, M. The Impact of Globalization on CO2 Emissions in China. MPRA Paper 64450, University Library of Munich, Germany. 2015. Available online: https://mpra.ub.uni-muenchen.de/64450/ (accessed on 19 August 2020).

7. Grossman, G.; Krueger, A. Environmental impacts of a North American free trade agreement. Natl. Bur. Econ. 1991. [CrossRef]

8. Grossman, G.; Krueger, A. Economic environment and the economic growth. Q. J. Econ. 1995, 110, 353-377. [CrossRef]

9. Lucas, R.E.B.; Wheeler, D.; Hettige, H. Economic development, environ- mental regulation and the international migration of toxic industrial pollution: 1960-1988. In International Trade and the Environment; Low, P., Ed.; World Bank: Washington, DC, USA, 1992; pp. 67-87.

10. Vincent, J.R. Testing for environmental Kuznets curves within a developing country. Environ. Dev. Econ. 1997, 2, 417-431. [CrossRef]

11. Pellow, D.N.; Brehm, H.N. An Environmental Sociology for the Twenty-First Century. Annu. Rev. Sociol. 2013, 39, 229-250. [CrossRef]

12. International Monetary Fund. Globalization: A Brief. Overview. Available online: https://www.imf.org/external/np/exr/ib/20 08/053008.htm (accessed on 23 October 2020).

13. Suci, S.C.; Asmara, A.; Mulatsih, S. The impact of globalization on economic growth in ASEAN. Bisnis Birokrasi J. 2016, 22, 79-87. [CrossRef]

14. Kacowicz, A.M. Regionalization, globalization, and nationalism: Convergent, divergent, or overlapping? Alternatives 1999, 24, 527-556. [CrossRef]

15. Osterhammel, J. Nationalism and Globalization. In The Oxford Handbook of the History of Nationalism; Oxford University Press: Oxford, UK, 2013; pp. 694-712.

16. Robertson, R.; White, K.E. What is globalization. The Blackwell Companion to Globalization; Wiley: Hoboken, NJ, USA, 2007; pp. 54-66.

17. Goryakin, Y.; Lobstein, T.; James, W.P.; Suhrcke, M. The impact of economic, political and social globalization on overweight and obesity in the 56 low and middle income countries. 2015. Soc. Sci. Med. 1982, 133, 67-76. [CrossRef] [PubMed]

18. Guzel, A.E.; Arslan, U.; Acaravci, A. The impact of economic, social, and political globalization and democracy on life expectancy in low-income countries: Are sustainable development goals contradictory? Environ. Dev. Sustain. 2021, 133, 1-18.

19. Gygli, S.; Haelg, F.; Potrafke, N.; Sturm, J.E. The KOF globalisation index-revisited. Rev. Int. Organ. 2019, 14, 543-574. [CrossRef]

20. ILO. Social Dimension of Globalization. 2003. Available online: https://www.ilo.org/public/english/wcsdg/globali/globali.htm (accessed on 20 August 2021).

21. Adesina, O.S. The negative impact of globalization on Nigeria. Int. J. Humanit. Soc. Sci. 2012, 2, $193-201$.

22. Dreher, A. Does Globalization Affect Growth? Evidence from a new Index of Globalization. Appl. Econ. 2006, 38, 1091-1110. [CrossRef]

23. Figge, L.; Martens, P. Globalisation continues: The Maastricht globalisation index revisited and updated. Globalizations 2014, 11, 875-893. [CrossRef]

24. Vujakovic, P. How to measure globalisation? A new globalisation index (NGI). Atl. Econ. J. 2010, 38, 237. [CrossRef]

25. Martens, P.; Raza, M. Is globalisation sustainable? Sustainability 2010, 2, 280-293. [CrossRef]

26. Saint Akadiri, S.; Lasisi, T.T.; Uzuner, G.; Akadiri, A.C. Examining the impact of globalization in the environmental Kuznets curve hypothesis: The case of tourist destination states. Environ. Sci. Pollut. Res. 2019, 26, 12605-12615. [CrossRef]

27. Borghesi, S.; Vercelli, A. Sustainable Globalisation. Ecol. Econ. 2003, 44, 77-89. [CrossRef]

28. Kilic, C. Effects of Globalization on Economic Growth: Panel Data Analysis for Developing Countries. Pet. Gas. Univ. Ploiesti Bull. Tech. Ser. 2015, 67, 1-11.

29. Ying, Y.H.; Chang, K.; Lee, C.H. The Impact of Globalization on Economic Growth. Rom. J. Econ. Forecast. 2014, 17, 25-34. Available online: https:/ /EconPapers.repec.org/RePEc:rjr:romjef:v::y:2014:i:2:p:25-34 (accessed on 10 January 2021).

30. Samimi, P.; Jenatabadi, H.S. Globalization and economic growth: Empirical evidence on the role of complementarities. PLoS ONE 2014, 9, e87824. [CrossRef] [PubMed]

31. Nistor, C. Positive and negative effects of globalization. Univ. Bucuresti. Analele. Ser. Stiinte Econ. Si Adm. $2007,1,152$. 
32. Dreher, A.; Gaston, N. Has globalization increased inequality? Rev. Int. Econ. 2008, 16, 516-536. [CrossRef]

33. Khan, H.A. Globalization: Challenges and opportunities. Rev. Int. Bus. Res. 2004, 15, 276-291.

34. Syvitski, J.; Waters, C.N.; Day, J.; Milliman, J.D.; Summerhayes, C.; Steffen, W.; Williams, M. Extraordinary human energy consumption and resultant geological impacts beginning around $1950 \mathrm{CE}$ initiated the proposed Anthropocene Epoch. Commun. Earth Environ. 2020, 1, 1-13. [CrossRef]

35. Kasperowicz, R. Economic growth and $\mathrm{CO}_{2}$ emissions: The ECM analysis. J. Int. Stud. 2015, 8, 91-98.

36. Dinda, S. Globalization and Environment: Can Pollution Haven Hypothesis alone Explain the Impact of Globalization on Environment? MPRA Paper 50590; University Library of Munich: München, Germany, 2006. Available online: https://mpra.ub.uni-muenchen. $\mathrm{de} / \mathrm{id} /$ eprint/50590 (accessed on 23 November 2020).

37. Sabir, S.; Gorus, M.S. The impact of globalization on ecological footprint: Empirical evidence from the South Asian countries. Environ. Sci. Pollut. Res. 2019, 26, 33387-33398. [CrossRef] [PubMed]

38. Abbes, S. Factors Affecting Transport Sector $\mathrm{CO}_{2}$ Emissions in Eastern European Countries: An LMDI Decomposition Analysis. In Engineering Proceedings; Multidisciplinary Digital Publishing Institute: Basel, Switzerland, 2021; Volume 5, p. 25.

39. Amin, A.; Altinoz, B.; Dogan, E. Analyzing the determinants of carbon emissions from transportation in European countries: The role of renewable energy and urbanization. Clean Technol. Environ. Policy 2020, 22, 1725-1734. [CrossRef]

40. Ding, J.; Jin, F.; Li, Y.; Wang, J.E. Analysis of transportation carbon emissions and its potential for reduction in China. Chin. J. Popul. Resour. Environ. 2013, 11, 17-25. [CrossRef]

41. Eurostat, Environmental Tax Statistics. Available online: https://ec.europa.eu/eurostat/statistics-explained/index.php?title= Environmental_tax_statistics (accessed on 4 February 2021).

42. Aydin, C.; Esen, Ö. Reducing $\mathrm{CO}_{2}$ emissions in the EU member states: Do environmental taxes work? J. Environ. Plan. Manag. 2018, 61, 2396-2420. [CrossRef]

43. Silajdzic, S.; Mehic, E. Do Environmental Taxes Pay Off? The Impact of Energy and Transport Taxes on $\mathrm{CO}_{2}$ Emissions in Transition Economies. South. East. Eur. J. Econ. Bus. 2018, 13, 126-143. [CrossRef]

44. Georgescu-Roegen, N. The Entropy Law and the Economic Process; Harvard University Press: Cambridge, MA, USA, 1971.

45. Martínez-Alier, J.; Pascual, U.; Vivien, F.-D.; Zaccai, E. Sustainable De-Growth: Mapping the Context, Criticisms and Future Prospects of an Emergent Paradigm. Ecol. Econ. 2010, 69, 1741-1747. [CrossRef]

46. Euler, J. The Commons: A Social Form that Allows for Degrowth and Sustainability. Capital. Nat. Soc. 2019, 30, 158-175. [CrossRef]

47. Pollin, R. Advancing a Viable Global Climate Stabilization Project: Degrowth versus the Green New Deal. Rev. Radic. Political Econ. 2019, 51, 311-319. [CrossRef]

48. Schor, J.B.; Jorgenson, A.K. Is it Too Late for Growth? Rev. Radic. Political Econ. 2019, 51, 320-329. [CrossRef]

49. Im, K.S.; Pesaran, M.H.; Shin, Y. Testing for unit roots in heterogeneous panels. J. Econom. 2003, 115, 53-74. [CrossRef]

50. Choi, I. Unit root tests for panel data. J. Int. Money Financ. 2001, 20, 249-272. [CrossRef]

51. Pedroni, P. Critical Values for Cointegration Tests in Heterogeneous Panels with Multiple Regressors. Oxf. Bull. Econ. Stat. 1999, 61, 653-670. Available online: https:/ / EconPapers.repec.org/RePEc:wil:wileco:2000-02 (accessed on 26 March 2021). [CrossRef]

52. Dumitrescu, E.I.; Hurlin, C. Testing for Granger non-causality in heterogeneous panels. Econ. Model. 2012, 29, 1450-1460. [CrossRef]

53. Arellano, M.; Bond, S. Some tests of specification for panel data: Monte Carlo evidence and an application to employment equations. Rev. Econ. Stud. 1991, 58, 277-297. [CrossRef]

54. BP. Statistical Review of World Energy, 69th Edition. Available online: https://www.bp.com/en/global/corporate/energyeconomics/statistical-review-of-world-energy.html (accessed on 15 January 2021).

55. Lütkepohl, H. New Introduction to Multiple Time Series Analysis; Springer: Berlin/Heidelberg, Germany, 2005.

56. Conversi, D. The ultimate challenge: Nationalism and climate change. Natl. Pap. 2020, 48, 625-636. [CrossRef]

57. Duara, P. The Ernest Gellner Nationalism Lecture: Nationalism and the crises of global modernity. Nations Natl. 2021, 27, 610-622. [CrossRef] 